\title{
Nanocurcumin Preparation for Reducing Vcam-1 and IL-6 in High Fat Diet-Induced Hyperlipidemic Rats
}

\author{
Dimas Adhi Pradana*, Maulana Ardhi, Arifa Caryn Dea Utami Hasyono, Dzihni Meytasari, Farah \\ Deastasa Nabilah, Rochmy Istikharah and Lutfi Chabib
}

Department of Pharmacy, Faculty of Mathematics and Natural Sciences, Universitas Islam Indonesia Jl. Kaliurang, km. 14,5 Yogyakarta 55584 Indonesia

\begin{tabular}{l} 
Info Article \\
\hline Submitted: 6-12-2018 \\
Revised: $9-3-2019$ \\
Accepted: $13-3-2019$ \\
*Corresponding author \\
Dimas Adhi Pradana \\
Email: \\
086130405@uii.ac.id
\end{tabular}

\section{ABSTRACT}

Hyperlipidemia is a pathological condition due to lipid metabolism abnormalities. Increased and oxidized LDL in hyperlipidemia will trigger an inflammatory response and produce proinflammatory cytokines, such as vascular cell adhesion molecule-1 (VCAM-1) and Interleukin-6 (IL-6). Curcumin can be used as antioxidants, anti-inflammatory and antihyperlipidemia, but as it is practically insoluble in water, formulation of curcumin nanosuspension is made to improve the effects of curcumin therapy. This study was conducted to determine the activities of nanocurcumin preparation as preventive measures for rats induced with hyperlipidemia. The test animals used were 49 male Wistar rats divided into 7 test groups: normal control group, negative control group, 80mg/kg BW/day curcumin control group, and nanosuspension curcumin dose of $80 \mathrm{mg} / \mathrm{kg} \mathrm{BW} /$ day, nanoemulsion curcumin dose of $80 \mathrm{mg} / \mathrm{kg} \mathrm{BW} /$ day, SNEDDS curcumin dose of $80 \mathrm{mg} / \mathrm{kg}$ BW/day and solid lipid nanoparticles dose of $80 \mathrm{mg} / \mathrm{kg} \mathrm{BW} /$ day. Provision of preventive measure was performed on days 1-67. On day 11-67, the induction of lard and egg yolk (1:1) was administered with a volume of $2 \mathrm{~mL} / 200 \mathrm{~g}$ of rat BW. On the $68^{\text {th }}$ day, blood samples were taken for the determination of VCAM-1 and IL- 6 parameters using Biotin-Streptavidin-Amplified Enzyme-Linked Immuno-sorbent Assay method. Data analysis of VCAM-1 and IL-6 levels between test groups were conducted by means of normality test and One-way ANOVA $(\mathrm{p}<0.05)$. Based on the data of VCAM-1 and IL-6 levels, nanocurcumin dose of $80 \mathrm{mg} / \mathrm{kg}$ BW preparation was able to significantly improve the preventive activity of curcumin compared to curcumin suspension dose of $80 \mathrm{mg} / \mathrm{kg}$ BW by reducing VCAM-1 levels in SNEDDS (53.260\%), nanoemulsion (52.737\%), nanosuspension (52.325\%) and solid lipid nanoparticles (51.444\%) and decreasing IL-6 levels in SNEDDS (33.030\%), nanoemulsion (31.568\%), nanosuspension (29.898\%), and solid lipid nanoparticles (28.875\%).

Keywords: high-fat diet, curcumin, SNEDDS, nanosuspension, nanoemulsion, solid lipid nanoparticles, VCAM-1, IL-6.

\section{INTRODUCTION}

Hyperlipidemia, a pathological condition caused by lipid metabolism disorders, is characterized by an increase in lipid fractions such as LDLcholesterol in the blood (Nelson, 2013). One of the hyperlipidemic conditions can occur due to a highfat diet treatment by providing high-fat ingredients to induce an increase in blood LDL (Murwani et al., 2006). Increased and oxidized LDL in the blood vessel walls will trigger an inflammatory response and produce proinflammatory cytokines, such as vascular cell adhesion molecule-1 (VCAM-1) and Interleukin-6 (IL-6) (Hansson, 2005). VCAM-1 plays a role in inflammatory cell recruitment by stimulating monocytes adhesion to the endothelial wall, which marks the initial stage of atherogenesis in both experimental animals and humans (Tanuwidjojo, 2005). IL-6 is a cytokine that can function as a predictor of coronary heart disease and has been proved to be involved in 
inflammatory disorders associated with atherosclerosis (Omoigui, 2007).

Increased atherosclerosis prevalence in Southeast Asia is dominated by hyperlipidemia as the major risk factor (Ricvan, 2015). Atherosclerosis can lead to death and predictably becomes a leading cause of morbidity and mortality in developing communities in 2020 due to their unhealthy lifestyle changes (Libby, 2005). In Indonesia, the prevalence of coronary heart disease in 2013 reached $1.5 \%$ or approximately $2,650,340$ people. This has placed coronary heart disease in the seventh largest prevalence rates of non- communicable diseases in Indonesia (Kemenkes, 2013).

Antioxidants, one of which is curcumin, can be used to inhibit molecular oxidation and free radicals in atherosclerosis. Extracts of Curcuma longa have proved to be capable of inhibiting nearly all expressions of VCAM- 1 by suppressed almost completely VCAM-1 protein expression. It is also reducing IL-6 production levels in rat cell tissue by blocked the mRNA expression of IL- 6 in the Lipopolysaccharide (LPS) induced vascular smooth muscle cells in vitro. (Kawasaki et al., 2015) (Yanti et al., 2014).

Curcumin as a natural compound is practically insoluble in water and has low bioavailability. Nano formulation has been proved to be able to improve curcumin dissolution and solubility (Carvalho et al., 2015), making it possible to increase the therapeutic efficacy of curcumin with nanoparticles formulation. This study aimed to examine the activities of a variety of nanocurcumin preparations compared to curcumin suspension as a preventive measure in high-fat diet-induced hyperlipidemic rats based on the levels of VCAM-1 and IL-6. Preventive measure research is performed with the underlying principle that prevention is better than cure.

\section{MATERIAL AND METHODS Equipment}

The equipment used was electric scales (Mettler Toledo ML-303 E), a set of laboratory glassware (Pyrex), micropipette, oral syringe, centrifugator, rotary evaporator (Heidolph), ELISA reader (Thermo Scientific), incubator (Memmert), ultra turrax (digital IKA T25), magnetic stirrer (IKA®18 BASIC), particle size analyzer (HORIBA Scientific Nano Partica SZ100), and ultrasonic homogenizer (HORIBA Scientific Nano Partica SZ100).

\section{Materials}

The test materials used in this study were pure curcumin pro analytic which was purchased from MERCK Singapore. Elisa VCAM-1 kit and Elisa Interleukin-6 kit were purchased from ExpressBio USA. Short chain chitosan, sodium tripolyphosphate and cremophor EL were purchased from SigmaAldrich Iceland. Sodium acetate distilled water was purchased from Ikapharmindo Putramas Jakarta Indonesia. Buffer acetate $\mathrm{pH} 4$ consisting of acetic acid $96 \% \mathrm{v} / \mathrm{v}$ alcohol, NaCMC, tween 80 , propylene glycol, miglyol 318, tween 20 and span 80 were purchased from Brataco Yogyakarta Indonesia. Glyceryl monostearate was purchased from PT. Sumber Berlian Kimia Jakarta Indonesia.

\section{Research Design}

This study employed the true experimental post-test control study. The test animals were physically healthy male Wistar rats fulfilling the weight range criteria (180-250g). Rats were fasted for $8 \mathrm{~h}$ before induction and treatment. A total of 49 male Wistar rats were divided into 7 groups each consisting of 7 rats, namely the normal control group, the negative control group (high-fat diet induction), the curcumin suspension control group dose of $80 \mathrm{mg} / \mathrm{kgBW} /$ day, the curcumin nanosuspension treatment group dose of $80 \mathrm{mg} /$ $\mathrm{kgBW} /$ day, the curcumin nanoemulsion treatment group dose of $80 \mathrm{mg} / \mathrm{kgBW} /$ day, the curcumin SNEDDS treatment group dose of $80 \mathrm{mg} / \mathrm{kgBW} /$ day, and the solid lipid nanoparticles curcumin treatment group dose of $80 \mathrm{mg} / \mathrm{kgBW} / \mathrm{day}$. Administration of preventive measure using curcumin suspension dose of $80 \mathrm{mg} / \mathrm{kgBW} /$ day and nanocurcumin dose of $80 \mathrm{mg} / \mathrm{kgBW} /$ day was carried out on days 1-67. On days 11-67, an induction of high-fat diet with lard and quail eggyolk was given (1: 1$)$.

\section{Curcumin Nanosuspension Preparation}

As much as $50 \mathrm{~mL}$ of $0.1 \%$ w/ curcumin solution was mixed with $50 \mathrm{~mL}$ of $0.02 \% \mathrm{w} / \mathrm{v}$ chitosan and stirred with a magnetic stirrer for 20 minutes at $60^{\circ} \mathrm{C}$. After $20 \mathrm{~min}, 6 \mathrm{~mL}$ of $0.01 \% \mathrm{w} / \mathrm{v}$ sodium tripolyphosphate was added and stirred for $20 \mathrm{~min}$. The mixed preparation was evaporated to remove ethanol solvent (Chabib et al., 2012).

\section{Curcumin Nanoemulsion Preparation}

As much as $5 \mathrm{~mL}$ miglyol and $15 \mathrm{~mL}$ of propylene glycol were mixed and stirred for $5 \mathrm{~min}$. Then, $0.8 \mathrm{mg}$ curcumin was dissolved and put into the mixture of miglyol and propylene glycol then 
stirred at $60^{\circ} \mathrm{C}$ for $10 \mathrm{~min}$. Tween 80 (25mL) was added and stirred for $30 \mathrm{~min}$. Aqua Bidestilata was added as much as $54.2 \mathrm{~mL}$ by means of titration then homogenized using vortex for $5 \mathrm{~min}$ (Lagonah, 2014)

\section{Curcumin SNEDDS Preparation}

Mixture 1 of cremophor EL and tween 20 as well as Mixture 2 of PEG and miglyol 318 were made. Each was sonicated for $2 \mathrm{~min}$ then both were mixed and re- sonicated for $1 \mathrm{~min}$. Curcumin was added to the mixture and then re-sonicated for 2min (Bagiana, 2015).

\section{Solid Lipid Nanocurcumin Preparation}

A lipid phase consisting of Glyceryl monostearate (GMS) Span 80 and curcumin was dispersed into the aqueous phase consisting of aquadest and tween 80 while being heated at $75^{\circ} \mathrm{C}$ and stirred. The emulsion produced was then homogenized with ultra turrax at a speed of $30,000 \mathrm{rpm}$ for $5 \mathrm{~min}$ and ultrasonicated with $30 \%$ amplitude for $10 \mathrm{~min}$. The results were cooled at room temperature to produce SLN curcumin in the form of emulsion (Mujib, 2011).

Measurement of nanoparticle size distribution and stability was conducted using Particle Size Analyzer (PSA) at the Pharmacy Technology Laboratory of Islamic University of Indonesia. Nanoparticle is confirmed when the particle size is $10-1000 \mathrm{~nm}$ and Polydispersity index $<0.3$.

\section{Curcumin Suspension Preparation}

As much as $8 \mathrm{mg}$ of curcumin was weighed thoroughly, and then $0.5 \% \mathrm{w} / \mathrm{v}$ Na-CMC solution was added until the volume reached $50 \mathrm{~mL}$. The concentration of curcumin suspension obtained was $0.016 \% \mathrm{w} / \mathrm{v}$.

\section{High-Fat Diet Induction}

Induction of a high-fat diet was carried out according to the method employed in a previous study (Sa'adah and Pratiwi, 2016) with a modification in the use of lard and quail egg-yolk (a ratio of 1:1) orally each day for 57 days. The volume of lipid mixture administered to the rats was $2 \mathrm{~mL} /$ $200 \mathrm{~g} / \mathrm{BW}$

\section{Determination of VCAM-1and IL6 Levels}

Determination of VCAM-1 and Interleukin- 6 levels was carried out by taking blood plasma samples of each group on 68th day. The blood plasma sample was then analyzed by means of Biotin-Streptavidin- Amplified Enzyme-Linked Immunosorbent Assay. Tests were carried out using an ELISA kit produced by ExpressBio with duplo samples.

\section{Blood sample collection}

Blood samples were taken as much as 500 $\mathrm{mL}$ from orbital vein of Rats on day $68^{\text {th }}$. Then the blood is processed into plasma by adding heparin as an anticoagulant and centrifuging for about $15 \mathrm{~min}$ at $4000 \mathrm{rpm}$.

\section{ELISA kit protocol for VCAM and IL-6 examination}

Wells and $37^{\circ} \mathrm{C}$ incubator were prepared, and wells were washed two times with $350 \mu \mathrm{L}$ of wash buffer (left for $\pm 1 \mathrm{~min}$ prior to disposal). Then, $100 \mu \mathrm{L}$ of standard solution, $100 \mu \mathrm{L}$ of sample, and $100 \mu \mathrm{L}$ of standard dilution buffer (blank) were added into each well. Wells were covered with plate sealers and incubated at a temperature of $37^{\circ} \mathrm{C}$ for $90 \mathrm{~min}$. Plate sealers were removed and the well content was discarded. The wells were rinsed twice with $350 \mu \mathrm{L}$ wash buffer and left for $1 \mathrm{~min}$, then the buffer was disposed into the sink and the content was slammed onto tissue. A total of $100 \mu \mathrm{L}$ biotin-labeled antibody solution was added to each well. The wells were covered with plate sealers and incubated at $37^{\circ} \mathrm{C}$ for 60 min. The plate sealers were opened and content of the wells was discarded. Wells were rinsed three times using $350 \mu \mathrm{L}$ wash buffer. Before being disposed into the sink and slammed onto tissue, the content was let rest for $1 \mathrm{~min}$. Into each well was added $100 \mu \mathrm{L}$ SABC solution followed by sealing with plate sealers and aluminum foil and incubation at $37^{\circ} \mathrm{C}$ for $30 \mathrm{~min}$. Plate sealers were removed and well content was discarded. Wells were washed five times using $350 \mu \mathrm{L}$ wash buffer and left for $1 \mathrm{~min}$ prior to disposal into the sink and a smash onto tissue. Each well was filled with $90 \mu \mathrm{L}$ TMB substrate solution, closed with aluminum foil, and incubated at $37^{\circ} \mathrm{C}$ for $30 \mathrm{~min}$ in the dark. Next, $50 \mu \mathrm{L}$ stop solution was put into each well and mixed to obtain a homogeneous solution. The color would instantly turn into yellow, and result was read for the optical density at $450 \mathrm{~nm}$ absorbance in a microplate reader immediately after the addition of stop solution (XpressBio, 2018a) (XpressBio, 2018b). 
Table I. Particle size, Polydispersity index, and Zeta potential of nanocurcumin preparation

\begin{tabular}{lccc}
\hline Preparation & Particle size (nm) & Polydispersity index & Zeta Potential (mV) \\
\hline Nanosuspension & $154.6 \pm 2.10$ & $0.23 \pm 0.10$ & $+22.5 \pm 0.2$ \\
Nanoemulsion & $74.9 \pm 0.80$ & $0.36 \pm 0.02$ & $-37.4 \pm 1.2$ \\
SNEDDS & $69.0 \pm 1.15$ & $0.32 \pm 1.15$ & $-39.5 \pm 0.2$ \\
SLN & $150.4 \pm 2.20$ & $0.45 \pm 0.20$ & $-62.3 \pm 0.1$ \\
\hline
\end{tabular}

Criteria of Nano Preparations: Particle size: 10-1000nm (Rawat et al., 2006) Polydispersity index < 0.5 (Abdassah, 2017) Zeta potential > +/- $30 \mathrm{mV}$ (Abdassah, 2017)

\section{Calculating VCAM-1 and IL-6 Concentrations \\ OD of Sample $=$ OD of sample - OD of blank OD=Optical Density}

The sample concentration was calculated based on the linear regression of absorbance (optical density) obtained from the ELISA plate reader relative to the standard concentration series. Formula for the percentage of reduced concentration:

Percentage of Reduced Concentration (\%) = $\frac{\text { conc. of negative control-conc. of curcumin }}{\text { conc. of negative control }} \times 100 \%$

\section{Data analysis}

Data of VCAM-1 and IL-6 levels from each test group was analyzed in Normality test and compared using One-way ANOVA test with Posthoc Tukey $(\mathrm{p}<0.05)$.

\section{RESULTS AND DISCUSSION}

This research was approved to be carried out and can be carried out treatment on male Wistar rat test animals in accordance with the approval of Ethical Clearance by the Medical and Health Research Ethics Committee of the Faculty of Medicine, Islamic University of Indonesia, Yogyakarta with number 76 / Ka.Kom.Et / 70 / KE / IV / 2018.

\section{Characterization of nanocurcumin}

From the characterization of four nanocurcumin preparations, the SNEDDS preparation has the smallest particle size, which is below $100 \mathrm{~nm}$. The particle size of SNEDDS is smaller than that of the other preparations due to the high-energy method used in the preparation process. Meanwhile, the best zeta potential is found in the solid lipid nanocurcumin preparation because it consists of solid lipid that can form capsules and absorb active substances within, enabling them to prevent environmental degradation and so the preparation becomes more stable.

Table I give information that all nanocurcumin preparation show the particle size, polydispersity index and zeta potential measurements are in accordance with the nanoparticle criteria. With the smaller particle size, drug delivery will more optimally reach the target of drug action. In addition, the drug will also be protected by the carrier when passing through several barriers such as acidic and basic conditions (Nasr et al., 2016)

Polidispersity index is a value that indicates the normal distribution of particle size or distribution. Standard value of polidispersity index is $<0.50$ (Abdassah ,2017).

Zeta potential describes the charge difference between a dispersion medium and the liquid layer attached to the dispersed particle of substance. Zeta potential also indicates the magnitude of charge repulsion among dispersed particles in a liquid medium. Such repulsion occurs because each of the surfaces of dispersed particle has the same charge. The higher the zeta potential of a particle is, the more significant the repulsion among particles is. Repulsion prevents aggregation or flocculation between globules, leading to a more stable nanoemulsion preparation. A nanoemulsion preparation is required to have $\pm 30 \mathrm{mV}$ zeta potential to maintain good stability.

Zeta potential value shows the magnitude of repulsion between droplets. The higher the value is, the stronger the repulsion between droplets is, thus avoiding aggregation. A nanoemulsion system stabilized by a surfactant is naturally ionic since the charge of droplet surface comes from the ion of surfactant hydrophilic groups. Meanwhile, in a nanoemulsion system stabilized by a nonionic surfactant, the surface charge comes from the adsorption of ions in the water phase or due to a friction between droplets and their dispersion medium (Rosen, 2004). 
Table II. Mean levels of VCAM-1 \pm SE

\begin{tabular}{cc}
\hline Sample (n=5) & Kadar VCAM-1 (ng/mL) \\
\hline Normal & $0.985 \pm 0.336^{\mathrm{b}, \mathrm{c}}$ \\
Negative control & $6.627 \pm 0.758^{\mathrm{a}, \mathrm{d}, \mathrm{e}, \mathrm{f}, \mathrm{g}}$ \\
Curcumin suspension control & $5.546 \pm 0.441^{\mathrm{a}, \mathrm{d}, \mathrm{e}, \mathrm{f}, \mathrm{g}}$ \\
Curcumin Nanosuspension & $3.159 \pm 0.481^{\mathrm{b}, \mathrm{c}}$ \\
Curcumin SNEDDS & $3.097 \pm 0.282^{\mathrm{b}, \mathrm{c}}$ \\
Solid Lipid Nanocurcumin & $3.218 \pm 0.348^{\mathrm{b}, \mathrm{c}}$ \\
Curcumin Nanoemulsion & $3.132 \pm 0.475^{\mathrm{b}, \mathrm{c}}$ \\
\hline
\end{tabular}

Statistical test results from One-way ANOVA and Post-hoc Tukey $(\mathrm{p}<0.05$ ): (a) significantly different from the normal control group, (b) significantly different from the negative control group, (c) significantly different from the curcumin suspension control group, (d) significantly different from the curcumin nanosuspension group, (e) significantly different from the curcumin SNEDDS group, (f) significantly different from the SLN curcumin group, (g) significantly different from the curcumin nanoemulsion group.

In an o/w nanoemulsion system containing a nonionic surfactant, the surfactant will form a film layer on the droplet surface. Such layer prevents droplet aggregation in the dispersion medium (Lazaridis et al., 1999)(Rosen, 2004).

\section{Determination of VCAM-1 Levels}

In this study, VCAM-1 levels were determined using the Biotin-StreptavidinAmplified Enzyme-Linked Immunosorbent Assay (BSA-ELISA) method. The BSA-ELISA system is a modification of the standard ELISA to increase the sensitivity of ELISA testing. Level determination was carried out on day 68 for each test group. Data of VCAM- 1 levels in each group (Table II).

Based on statistical analysis, the mean VCAM-1 level in the normal group is significantly different $(p<0.05)$ from that in the negative control group. This data shows that the induction of highfat diet with lard and quail egg-yolk can significantly increase the levels of VCAM-1 in negative control rats, marking the success of the method to induce high-fat diet in rats. Quail eggs and lard are examples of animal food-source containing high saturated fat and cholesterol. The composition of lard includes saturated fatty acids (1\% myristate, $25 \%$ palmitate, and $15 \%$ stearic acid) and unsaturated fatty acids (oleic 50\%, 6\% linoleic, and the remaining 3\%) which can increase cholesterol concentration in the blood by 1525\%(Sa'adah, and Pratiwi, 2016).

VCAM-1 level in rats with curcumin suspension at a dose of $80 \mathrm{mg} / \mathrm{kgBW}$ does not differ significantly ( $p>0.05$ ) from that in negative control rats, showing the disability of curcumin suspension to reduce VCAM-1 levels in high-fat diet-induced rats. Meanwhile, the levels of VCAM-1 in rats treated with nanocurcumin at a dose of 80mg/ kgBW significantly decrease $(\mathrm{p}<0.05)$ indicating the ability of nanocurcumin to reduce VCAM-1 levels in high-fat diet- induced rats. The antioxidant activity in curcumin is considered to relate to the reduction of VCAM-1 levels by capturing free radicals to reduce cell damage in atherosclerosis formation; therefore, VCAM- 1 levels in the endothelial blood-vessel tissue can decrease. The high antioxidant content of curcumin can be observed in the structure known as functional groups, such as $\beta$-diketone groups, carbon double bonds, and phenyl rings, containing a number of hydroxyl and methoxy substituents that play a role in donating their hydrogen groups to capture oxygen free-radicals which also play an important role in the initial formation lipid peroxidation (Shin et al., 2011)(Nurtamin, 2014).

The percentage of decrease in VCAM-1 levels of nanocurcumin is higher than that of curcumin suspension. The results of variance analysis (ANOVA) and Tukey test show significant differences $(p<0.05)$ between VCAM-1 levels in the curcumin suspension group and those in the nanocurcumin group. This indicates that curcumin SNEDDS preparation has the best results among other nano preparations. It is because curcumin SNEDDS is able to increase drug surface area, thus improving curcumin bioavailability. The small particle size of curcumin SNEDDS also has an impact on the delivery system of drug particles in vitro by improving drug solubility which therefore increases the permeability of drug molecules across the intestinal membrane (Shakeel et al., 2013). 
Table III. Mean IL-6 levels \pm SE

\begin{tabular}{cc}
\hline Sample (n=5) & IL-6 Level (pg/mL) \\
\hline Normal & $62.933 \pm 3.148$ b,c \\
Negative control & $108.916 \pm 5.968^{\mathrm{a}, \mathrm{d}, \mathrm{e}, \mathrm{f}, \mathrm{g}}$ \\
Curcumin suspension control & $96.067 \pm 10.362^{\mathrm{a}, \mathrm{d}, \mathrm{e}, \mathrm{f}, \mathrm{g}}$ \\
Curcumin Nanosuspension & $76.351 \pm 3.994 \mathrm{~b}, \mathrm{c}$ \\
Curcumin SNEDDS & $72.933 \pm 7.238^{\mathrm{b}, \mathrm{c}}$ \\
Solid Lipid Nanocurcumin & $77.466 \pm 6.065^{\mathrm{b}, \mathrm{c}}$ \\
Curcumin Nanoemulsion & $74.533 \pm 6.762^{\mathrm{b}, \mathrm{c}}$ \\
\hline
\end{tabular}

Statistical test results from One-way ANOVA and Post-hoc Tukey $(\mathrm{p}<0.05)$ : (a) significantly different from the normal control group, (b) significantly different from the negative control group, (c) significantly different from the curcumin suspension control group, (d) significantly different from the curcumin nanosuspension group, (e) significantly different from the curcumin SNEDDS group, (f) significantly different from the SLN curcumin group, (g) significantly different from the curcumin nanoemulsion group.

\section{Determination of Interleukin-6 Levels}

In this study, IL-6 levels are determined using the Biotin-Streptavidin-Amplified EnzymeLinked Immunosorbent Assay(BSA- ELISA) method. Data of IL-6 levels in each group (Table III).

Based on the statistical analysis, the mean IL-6 level in the normal group shows a significant difference $(p<0.05)$ compared to that in the negative control group. Such data shows that the induction of high-fat diet with lard and quail egg yolk can significantly increase IL-6 levels in negative control rats, indicating the success of the method used to induce a high-fat diet condition in rats.

IL-6 levels in rats given curcumin suspension at a dose of $80 \mathrm{mg} / \mathrm{kgBW}$ do not differ significantly $(p>0.05)$ from those in negative control rats, indicating that the administration of curcumin suspension is not able to reduce IL-6 levels in high-fat diet- induced rats. On the other hand, IL-6 levels in rats with nanocurcumin at a dose of $80 \mathrm{mg} / \mathrm{kgBW}$ show a significant decrease $(\mathrm{p}<0.05)$, marking the ability of nanocurcumin to reduce IL- 6 levels in high-fatdiet-induced rats.

Levels of IL-6 in rats with nanocurcumin treatment are not significantly different ( $p>0.05$ ) from those in normal rats. This indicates that nanocurcumin preparation is effective in reducing IL-6 levels to nearly normal. Decreased IL-6 levels in the nanocurcumin treatment group are closely related to the activity of curcumin as an antioxidant and anti-inflammatory. The antioxidant activity of curcumin reduces IL- 6 levels because it can capture free radicals that cause oxidative stress. When free radicals are captured, oxidation of low density lipoprotein (LDL) into oxidized low density lipoprotein (Ox-LDL) can be prevented, thus averting endothelial dysfunction as well as reducing IL-6 levels and adhesion molecules, such as VCAM-1 in the endothelium of blood vessel tissue (Sumardika, 2012). Curcumin is rich in antioxidant because its structure consists of phenolic hydroxyl groups and $\beta$-diketone groups, which function as free radical scavengers in an antioxidative mechanism (Rosidi et al., 2014). Not only antioxidant activities, curcumin also has antiinflammatory activities. Curcumin can inhibit the formation of prostaglandin and suppress the activity of cyclooxygenase enzyme, thus reducing inflammation (Basnet and Skalko-Basnet, 2011). Curcumin is also able to downregulate transcription factors, such as nuclear factor kappalight-chain enhancer of activated B cells (NF-kB) receptor factor and activator protein 1 (AP-1). The AP-1 transcription factor acts to regulate the expression of various cell types that are important for cell proliferation, differentiation, and apoptosis. Therefore, curcumin can suppress inflammatory response in the blood vessels, which then reduces the expression of adhesion molecules and cytokines that can facilitate the formation of plaques on the walls of blood vessels (Nurtamin, 2014).

The percentage of reduction in IL-6 levels from curcumin SNEDDS is higher than that from groups of nanosuspension, nanoemulsion, solid lipid nano, and curcumin suspension, leading to a conclusion that the design of curcumin SNEDDS formulation can increase the preventive activities of curcumin and is better than the other three designs of nanocurcumin formulation as well as curcumin suspension in reducing IL-6 levels in rats. This is because the formulation of curcumin SNEDDS preparation can increase the solubility of 
curcumin, and the very small particle size affects the distribution of drug molecules to go easily through the intestinal wall by binding to lipoproteins and carrying drug molecules to the lymphatic system, thereby preventing drug molecules from passingthe liver or first pass effect which results in increased bioavailability of curcumin (Makadia et al., 2013).

\section{CONCLUSION}

Nanocurcumin preparation is able to increase the preventive activities of curcumin significantly better than curcumin suspension by reducing VCAM-1 levels in SNEDDS preparation (53.260\%), nanoemulsion (52.737\%), nanosuspension (52.325\%), and solid lipid nano (51.444\%) as well as decreasing IL-6 levels in SNEDDS (33.030\%), nanoemulsion (31.568\%), nanosuspension (29.889\%), and solid lipid nanoparticles $(28.875 \%)$ in male Wistar rats induced with lard and quail egg yolk.

\section{ACKNOWLEDGEMENT}

Our gratitude goes to the Directorate of Research and Community Service of the Universitas Islam Indonesia for the research grants that have been given and also to the Laboratory of Pharmacology and Laboratory of Pharmaceutical Technology Department of Pharmacy Universitas Islam Indonesia for the supporting fascilities.

\section{REFERENCES}

Abdassah Nanopartikel dengan Gelasi Ionik. Farmaka. 15(1):45-52.

Bagiana IK. 2014. Pengembangan Nanogamavuton0 dengan Formulasi SNEDDS sebagai Kandidat Obat Analgetik dan Antiinflamasi [Tesis]. Yogyakarta: Universitas Gadjah Mada

Basnet P., and Skalko-Basnet N. 2011. Curcumin: An Anti-Inflammatory Molecule from a Curry Spice on the Path to Cancer Treatment. Molecules, 16(6), 4567-4598.

Carvalho D de M., Takeuchi KP., Geraldine RM., Moura CJ de., and Torres MCL. 2015. Production, solubility and antioxidant activity of curcumin nanosuspension. Food Science and Technology (Campinas), 35(1), 115-119.

Chabib L., Martien R., and Ismail H. 2012. Formulation Of Nanocurcumin Using Low Viscosity Chitosan Polymer And Its Cellular Uptake Study Into T47d Cells, Indonesian Jl Pharm. 23(1) : 27-35.
Hansson GK. 2005. Inflammation, Atherosclerosis, and Coronary Artery Disease. The New England J.f Medicine. 352:1685-1695.

Kawasaki K., Muroyama K., Yamamoto N., and Murosaki S. 2015. A hot water extract of Curcuma longa inhibits adhesion molecule protein expression and monocyte adhesion to TNF- $\alpha$-stimulated human endothelial cells. Bioscience, Biotechnology, and Biochemistry, 79(10), 1654-1659.

Kemenkes. 2013. Pusat Data dan Informasi Kementrian Kesehatan Republik Indonesia diambil dari: URL: http://www.depkes.go.id/article/view/170 73100005/penyakit-jantung- penyebabkematian-tertinggi- kemenkes-ingatkancerdik.

Lagonah R. 2014. Formulasi Sediaan Nanoemulsi Ibuprofen dengan Kombinasi Surfaktan Tween 80 dan Lesitin serta Uji Permeasi In Vitro [skripsi]. Universitas Islam Indonesia, Yogyakarta.

Lazaridis N., Alexopoulos AH., Chatzi EG., and Kiparissides C. 1999. Steric stabilization in emulsion polymerization using oligomeric nonionic surfactants. Chemical Engineering Science, 54(15), 3251-3261.

Libby P. 2005. Prevention and Treatment of Atherosclerosis in Harrison's Principles of Internal Medicine (16 ed., hlm. 1430-1434). The McGraw-Hill Companies, US.

Makadia HA., Bhatt AY., Parmar RB., Paun MJS., and Tank HM. 2013. Self-nano Emulsifying Drug Delivery System (SNEDDS): Future Aspects. AJPR, 3(1), 20-26.

Mujib MA. 2011. Pencirian nano Partikel Kurkuminoid Tersalut Lemak Padat [skripsi]. Institut Pertanian Bogor, Bogor.

Murwani S., Ali M., and Muliartha K. 2013. Diet aterogenik pada tikus putih (Rattus novergicus strain Wistar) sebagai model hewan aterosklerosis. J. Kedokt. Brawijaya. 22:6-9.

Nasr A., Gardouh A., Ghonaim H., Abdelghany E., and Ghorab M. 2016. Effect Of Oils, Surfactants And Cosurfactants On Phase Behavior And Physicochemical Properties Of Self-Nanoemulsifying Drug Delivery System (Snedds) For Irbesartan And Olmesartan. International Journal of Applied Pharmaceutics, 8(1) : 13-24.

Nelson RH. 2013. Hyperlipidemia as a Risk Factor for Cardiovascular Disease. Primary care, 40(1), 195-211. 
Nurtamin T. 2014. Potensi Curcumin untuk Mencegah Aterosklerosis. Dalam Continuing Professional Development. Ikatan Apoteker Indonesia.41(8):633-635.

Omoigui S. 2007. The Interleukin-6 inflammation pathway from cholesterol to aging - Role of statins, bisphosphonates and plant polyphenols in aging and age-related diseases. Immunity \& Ageing, 4(1): 1-22.

Ricvan DN. 2015. Meta analisis faktor risiko penyakit jantung koroner di Asia Tenggara. [Tesis]. Fakultas Kesehatan Masyarakat Universitas Andalas, Padang. p. 35.

Rosen MJ. 2004. Surfactants and interfacial phenomena (3rd ed). Hoboken, N.J: WileyInterscience.

Rosidi A., Khomsan A., Setiawan B., Riyadi H., and Briawan D. 2014. Potensi Temulawak (Curcuma xanthorrhiza Roxb) Sebagai Antioksidan. Laporan Penelitian. Prosiding Seminar Nasional dan Internasional Semarang. p. 1-8.

Sa'adah NN Pratiwi R. 2016. Profil Lipid dan Indeks Aterogenik Tikus Putih(Rattus norvegicus) Hiperlipidemia dengan Asupan Pelet Nasi dan Bekatul Beras Hitam (Oryza sativa L.). Semin. Nas. Biodiversitas VI:3-4.

Shakeel F., Haq N., El-Badry M., Alanazi FK., and Alsarra IA. 2013. Ultra fine super selfnanoemulsifying drug delivery system
(SNEDDS) enhanced solubility and dissolution of indomethacin. Journal of Molecular Liquids, Complete(180), 89-94.

Shin S-K., Ha T-Y., McGregor RA., and Choi M-S. 2011. Long-term curcumin administration protects against atherosclerosis via hepatic regulation of lipoprotein cholesterol metabolism. Molecular Nutrition \& Food Research, 55(12), 1829-1840.

Sumardika I. 2012. Water Extract of Sweet Potato Leaf Improved Lipid Profile and Blood SOD Content of Rats with High Cholesterol Diet. Medicina (Mex.), (43(2):67-71.).

Tanuwidjojo S. 2005. Pathogenesis of Atherosclerosis: The Role of Inflamation. Kumpulan naskah Semarang Cardiology Up date: New Trends in Cardiovascular Pharmacotherapy. Badan Penerbit Undip, Semarang.p 118-120.

XpressBio. 2018a. Rat IL-6 (Interleukin-6) Elisa kit. Express Biotech International.

XpressBio. 2018b. Rat VCAM-1 Elisa Kit. Express Biotech International.

Yanti Stephanie Yuliani Winarno FG., and Suhartono MT. 2014. Inhibition of Interleukin-6 Expression by Curcumin in Rat Vascular Smooth Muscle Explants $<$ I $>$ In Vitro</I>. American Journal of Biochemistry and Biotechnology, 10(4), 260-266. 